\title{
URGENCY OF CHARACTER BUILDING OF STUDENTS’ LOVE OF HOMELAND THROUGH THE HISTORICAL TEACHER' S ROLE IN STATE SENIOR HIGH SCHOOL 4 OF KAIRATU, AMBON
}

\author{
Rostin Talapessy, Dyah Kumalasari, Joniel Hendrik Salouw
}

The purpose of this study is to know how many efforts the historical teachers done in state senior high school 4 Kairatu Ambon in building students' love of homeland character through the historical subject by the qualitative approach. The data source in this research consists of primary and secondary data. The technique of data collecting used observation, interview, questionnaire and documentation. The technique of data analyzing in this research is conducted by four stages covering; 1) collecting, 2) data reduction, 3) data presentation, 4) making decision. The research founding indicates that there are three aspects, strived by the historical teacher of State Senior high school 4 kairatu in the effort of love of homeland character formation toward the students at school. Those aspects cover: discipline aspect, religious aspect and academic aspect. Discipline aspect covers controlling students to obligated attending the flag ceremony and anticipating the problem concerning with students' lateness in coming school on time. The religious aspect concerns with worship implementation at school, and academic aspect covers: teacher make the policy concerning with students' academic problem, such as students' absence during class hours, smoking at the school environment, students have no respect toward teachers and other students, and so on

Keyword: Love of homeland character, historical subject, teachers' effort

Copyright (C 2020, Rostin Talapessy, Dyah Kumalasari, Joniel Hendrik Salouw. This is an open access article under the CC BY license (http://creativecommons.org/licenses/by/4.0).

\section{Introduction}

A sense of love toward the homeland is crucial to be owned by every citizen living and born in a country. Love of homeland is a sense, arising in an individual covering an affection element toward the place they were born, and recognition as a citizen, willing to sacrifice and dedicate him/herself for their country where they live. When the sense love of homeland arises, someone will have a sense of own, proud, appreciate, serve, respect, maintain, defend and protect their homeland from various disturbances and threats. The sense of love of homeland becomes the main thing in a form of citizen's character. The sense of love of homeland can be performed by a sense of belonging, a sense of preserving, a sense of care, and a sense of wanting to advance. A citizen is obliged to arise the sense of love toward the homeland due to the homeland is a place where $\mathrm{He} /$ She lives.

However, the sense of love of homeland raises a question along with modern era as we are going through now days. This case can be observed from the phenomenon, occurring in an educational institution, where the nation character of children begins to fade by the globalization and technology era. The technology abuse changes the character and attitude of students in the educational world. This phenomenon is caused by the weakness of character building in educational institutions, for instance the senior high school students often overlook important things, such as the lack of their knowledge about the meaning. Another phenomenon found is that many feel proud using foreign products rather than local product. Besides that, the attitude to what they have done at school, such as being absent dur ing the lesson hours, not following the flag ceremony and being less fond of the national anthem. Those attitudes are the proofs that students' sense of love of homeland begins to be faded. Therefore, to shape the students' love of homeland character at school, it is needed the teachers' role in building the love of homeland character through the historical subject of Indonesia.

School is an educational institution that has a role in spreading a wise cultural value for students besides their parents and society as a main layer of character building. The school can be a culmination of students' character building. Therefore, to achieve the successfulness of the educational goal, it needs the teachers', the headmaster's and parents' role since both school and family environment have the important role in supporting the successful educational goal achievement.

The Indonesian historical subject in educational institutions is an appropriate subject in building the students' love of homeland character due to the fact that it contains heroic values, exemplary, pioneering, patriotism, nationalism, and an unyielding spirit, which underlies the process of building students' character and personality, contains treasure about national civilization, including Indonesian civilization. Historical subject is a process of community's change and development from time to time i.e. the past, present and the future. The purpose of historical subject in senior high school level which one of them listed in Government Education and Cultural Regulations No. 59 Year 2014 Attachment III about curriculum 2013 that the purpose of historical learning is to make students have the ability and knowledge about how to respect their nation. 


\section{Literature review}

Aman defines Historical material as an educational material, which is fundamental for the process of building and creation of Indonesian civilization in the future, cultivating an awareness of unity and solidarity in facing the threat of national disintegration, a useful moral teaching and wisdom in solving the crisis of multidimension, faced in real life [1].

National moral becomes one of the main determinants and sponsors of national welfare. The National education system is mandated in the Law Number 20 of 2003 to the teacher, government, society and students that have an expectation to achieve the national education goal, such as the development of students' potential, in order to be a human being, who believes and has devotion to the God Almighty, has the noble character, healthy, knowledgeable, capable, creative, independent, and becomes a democratic and responsible citizen. Since every citizen should have the same right to have a quality education as mandated in the Law Number 20 of 2003, Article 5 Paragraph (1). In connection with that matter, teacher's professionalism should be improved from time to time as mandated in the Law Number 20 of 2003 Article 24 Paragraph (1), which explicitly mandated that education should have the maximum quality and certification, concerning with teaching authority level, physically and mentally healthy, and has the ability to achieve the goals of national education [2].

The moral crisis in students and society is generally caused by the factors that indicate the failure of national education in building the character and moral of the citizen. Licona states that moral aspect concerns the national progress [3]. Meanwhile, according to Marianto, there are ten signs of decline, which should be watched out, i.e.

1) violence, increasing among the students,

2) bad use of language,

3) strong effect of peer group in a violence action,

4) the increase of self-destructive behavior such as abuse of drug and alcohol, behavior,

5) unclearness of the guideline of good and bad

6) decreased work ethic,

7) The lower respect for parents and teachers,

8) The lack of responsibility as a good citizen,

9) Often lies,

10) Hostility and suspicion between each other [4].

Based on the experts' opinion, it is indicated, that in the contemporary era, the young generation and the leader of the nation are not standing on moral value anymore. Asmani proposed that the globalization provides the facilities, needed for human, in both negative and positive effect [5].

In history learning, the teacher is an important factor for the success of it and an important factor in realizing the quality of learning, in this case it means that if the teacher has a good performance, he/she will be able to improve the quality of learning. Aman defines that teachers, who have good performance, will be able to deliver lessons well, be able to motivate students, are skilled in utilizing media, are able to guide and direct students in learning, so that students will have enthusi- asm in learning, enjoy the learning process and feel young [1]. They will understand the subject matter, delivered by the teacher.

According to Moh. Uzer Usman, a teacher is a professional position that requires special expertise, because this job cannot be done by anyone without expertise [6]. This is also explained by Hadi Supeno, who says that a teacher is someone, who because of his/her calling, uses most of his/her quiet time and mind to teach skills and attitudes to others in schools or formal educational institutions. Syatra also explained that the role of the teacher is to pay attention to students from various aspects, thus making it easier to achieve the goals, aspired by students from various aspects [7].

Mulyasa also stated that a teacher has a crucial role in the effort of improving students' moral [8]. Teachers should play an active role and put their position as professional staff, where they should be able to act as informant, facilitator, mediator, inspirator, motivator, organizer, supervisor, initiator and evaluator. Therefore, the teachers' role in shaping the love of homeland character through the historical subject determines the building of students' love of homeland character. Based on the description, the researcher is interested to conduct the research about how many efforts the teachers of state senior high school 4 kairatu have done in building students' love of homeland character through the historical subject.

\section{The aim and objectives of the study}

The aim of this study is to explore student character formation for the fatherland through the role of a history teacher of Indonesia in the public high school

To achieve the set aim, the following tasks have been solved:

1. What is the role of the teacher in shaping the character of love for the country through learning Indonesian history at SMA Negeri 4 Kairatu.

2. What are the obstacles, faced in the love of the country character through learning Indonesian history at SMA Negeri 4 Kairatu.

3. How are the efforts in shaping the character of love for the country through learning about Indonesian history at SMA Negeri 4 Kairatu

\section{Research method}

This research is qualitative, where the data source used consists of primary and secondary data. Primary data is obtained from the interview result toward:

1) vice principle of curriculum field of state senior high school 4 kairatu,

2) vice principle of student field,

3 ) historical teacher (2 people),

4) counseling teacher,

5) students (30 students).

Meanwhile, Secondary data is the data, obtained from the historical textbook, document such as lesson plan and syllabus and also another information concerning with the research subject. The technique of data collecting is done by four stages such as observation, interview, questionnaire and documentation. The technique of data analyzing, used in this research, is a qualitative technique of analysis where the data obtained were ana- 
lyzed qualitatively. The data analysis in this research is conducted in four stages i.e. data collecting, data reduction, data presenting and decision making.

\section{Result and discussion \\ 5.1. Teachers' Effort in Building Students' Love of homeland character}

In the case of building love of homeland character in the students of state senior high school 4 kairatu Ambon a strong effort which committed by the teachers, specially the historical teacher is needed. However, the effort always comes along with the obstacle factor. The existence of the obstacle factor is the challenge for a teacher. Therefore, this research is not only discussing about how many efforts are provided by the teacher in building students' love of homeland character but also analyzing how teachers solve the obstacle factor.

The observation result and document analysis indicate that the historical teachers' effort in preparing the activity of love of homeland is developed by structured teaching activity. In this case, making a complete learning media, such as academic calendar, syllabus and lesson plan in school year 2020, still be a guideline and reference in State senior high school 4 kairatu.

A teacher explains the subject material to students through the media. The media, used in the learning process, are the discussion method, used by a historical teacher. By using the discussion method, students learn directly about love of homeland character. Through this method students learn to control the emotion, receive other's opinion, cooperate and respect each other. The discussion method, used in a discussion, is one of the effective ways to build love of homeland character in students.

Closing activity, the teacher made a conclusion and did evaluation of the learning. Based on the observation result in the field, the teacher ended the learning activity by making a conclusion and a deal together about the topic discussion. The result of observation and documentation is supported by the interview result with Mrs. DL as a history teacher on January 28, 2020 that state as follow [9]:

"to build a love of homeland character, it is conducted by face to face learning, and individual evaluation through the assessment of children's character in learning. Besides individual assessment, the necessity to build the love of homeland character can be noticed from students' mistakes, such as coming school late, having no books during the learning process, and not obeying the school role and littering. Therefore, the historical teacher can assess every love of homeland character in students in the form of mistakes that students do. So, the minimum effort that the teacher and other school element can do is to give them motivation, such as good attitude and responsibility.

DL confirms that love of homeland can be developed in many ways, and one of them is by character building. Students should obey the school role, such as coming school on time, attending the flag ceremony, using Indonesian language well and keeping clean the school environment, keeping school reputation, etc. the opinion is supported by observation and document analysis, conducted by the research and it obtained the result that:

First, when students have been admitted in State senior high school 4 kairatu, they should follow the process which they have known as student orientation. This activity is conducted to build students' love of homeland character by coming to school on time. The purpose of the activity is to build students' discipline character. Second, concerning with worship. A teacher usually makes a check weather student follow the worship or not. Third, concerning with academic. This is the problem concerning with students' absence during lesson hours, students' lateness, students' bad attitude, and all those matters, must be conveyed by students' parents. Therefore, to resolve those matters, teachers and principals make special policies with the expectation that the policy can be effective to build the students' love of homeland character.

Moreover, the observation result is supported by MP's statement as a general history teacher on February 05, 2020 that [10]:

" the main value of the character, applied in State senior high school 4 kairatu is love of homeland character, where this character can make students do better and aware about their identity, to obey every school's role, such as wearing uniform according to the role, coming to school on time, keeping school cleanness, studying hard, etc. in building the students' love of homeland character, it is not only the historical teacher's responsibility, but one of all teachers at school. The love of homeland character becomes a priority and it is conducted by several ways to achieve the vision and mission of State senior high school 4 kairatu. Those ways are conducted by the expectation that students have awareness about the importance of love of homeland character and they are able to be a good leader, honest, integrated and responsible toward their country.

Besides that, SP propose that the love of homeland character will be developed continuously and students are expected to have a disciplined spirit and obey all the roles at school. Moreover, SP confirm that building the love of homeland character can also be done by reminding and advising and respecting each other. By reminding, students feel aware of their mistakes and respecting other students, so that they do not repeat their mistakes and can do something better in the future as a leader, who can defend their country through education, which is followed in earnest in these educational institutions.

\subsection{The Obstacles Faced in Building the Love} of |Homeland Character

The attitude of love of homeland that should be owned by all citizens in practice has not been fully implemented. The phenomenon occuring today is that the rise of corruption and young generations that are indifferent to all the problems indicate the attitude, which makes the decline of the love of homeland. Therefore, 
all teachers, especially historical teachers in the implementation of this character building can support the establishment of nationalism or love of homeland. However, the character building of love of homeland in State senior high school 4 Kairatu faces the obstacles that can hinder the process of character building of love of homeland and also supporting factors that can help teachers in the process of character building of love of homeland in State senior high school 4 Kairatu.

Based on the results of the research, there are several factors that are the obstacle for teachers, especially historical teachers in instilling the love of homeland in students, including:

1. Students do not fully understand the material, so that the students' character is difficult to build.

2. The lack of support from parents makes many students indifferent to school rules.

3. The determination of objectives in character building is still unclear.

4. The rapid development of communication tools has an impact on the mindset and attitude of students, who tend to be practical without any effort, therefore it obstructs the character building of love of homeland.

5. School facilities are not yet fully adequate.

5.3. The Solution Made by the Teacher as such and Historical Teacher in Resolving The Obstacle in Character Building of Love of Homeland in State Senior High School 4 Kairatu

In life, there are many trials and obstacles that can damage people and others. It is also cannot be denied that state senior high school 4 kairatu face several obstacles in building the character of love of homeland in students. It can also be caused by a lack of support from reliable human resources, facilities and infrastructure, which do not help, the lack of cooperation between teachers, indifferent attitude of students to the school environment and many other obstacles. But every problem, faced by humans, must have a solution.

ML suggested that teachers should take a personal approach, a persuasive approach; it is needed to be used for the aim of deepening the discipline of students because to build the character of students' love of homeland is not easy. There should be a disciplined attitude as well. When there are students that do the offense, the school always stimulates students to the good attitude and discipline character, to improve equality, to attend the flag ceremonies, to study in the classroom, joining other extra-curricular activities. All those activities are conducted by the expectation that the teacher can build the character value of the love of homeland.

The faith and obedience of the sense of security must be brought up. If any student is caught doing the offense, such as skipping school, arriving late to school, not attending the flag ceremony and another offense, historical teachers and teachers in the field of student affairs will bring the students up through socialization, ceremony, Students' Council worship. It is one of the mental coaching discipline of students that are against the rules, made by the school, to be the future leader of the nation that is good, authoritative, dignified and with high integrity.

Sometimes, parents want that everything run well, and they even demand a lot, but do not want to obey the rules, applied at school. So, the point is it needs everyone's cooperation to save students as the new generation of the nation from the actions that can take place in the future. When there are troubled students, teachers should collaborate with parents, counselling teachers to discuss and find the solution for students, committing the offence.

The same opinion was also expressed by ST, ST suggests that it needs a personal approach, a persuasive approach, deepening the work regarding student indiscipline because to build the character of students' love of homeland is not easy. One of the benchmarks of students' discipline and love of homeland is the level of obedience. So the point is it is necessary to collaborate with all the school parties to save the young generations as the next generation of the nation from actions that can run their future. On the other hand, SP also offers one solution that teachers should always keep an eye on students, who commit violations. If there is student, who commits the offense, school rules must be implemented and teachers must crack down firmly on students, who are caught arriving at school late, use school attributes that do not comply with school rules and make other offense.

\section{Conclusion}

Based on the research results that have been described above, it can be concluded that, in an effort to build the character of love for the motherland for the students of Negeri 4 Kairatu Ambon in this case the task is as follows:

1. To minimize some of the obstacles, often faced in building the character of love for the country.

2. the participation of all components, such as teachers and school principals, just cannot be separated from the parents of students in helping students with problems.

\section{References}

1. Aman, M. P. (2011). Model Evaluasi Pembelajaran Sejarah. Yogyakarta: Ombak, 160.

2. Desain Induk Pendidikan Karakter (2010). Kementrian Pendidikan Nasional. Jakarta: Kemendiknas.

3. Lickona, T. (1991). Educating for character: how our school can teach respect and responsibility. New York, Toronto, London, Sydney, Aucland: Bantam, 496.

4. Marianto, H. D. (2002). Pendidikan karakter: Paradigma baru dalam pembentukan manusia berkualitas (character education: new paradigma to human capacity building).

5. Ma'mur, A. J. (2012). Buku panduan internalisasi pendidikan karakter di sekolah. Yogyakarta: DIVA Press, 203.

6. Usman, M. U. (2002). Menjadi Guru Profesional. Bandung: PT. Remaja Rosdakarya, 154.

7. Syatra, N. Y. (2013). Desain Relasi Afektif Guru Dan Murid. Yogyakarta: Buku Biru, 180.

8. Mulyasa, E. (2009). Praktik Penelitian Tindakan Kelas. Bandung: Rosda Karya. 
9. Latuheru, D. (2020). Hasil wawancara Pribadi. SMA Negeri 4 Kairatu.

10. Pesulima, M. (2020). Hasil Wawancara Pribadi. MA Negeri 4 Kairatu.

Received date 21.10.2020

Accepted date 26.11.2020

Published date 25.12.2020

Rostin Talapessy, Pendidikan Sejarah, Program Pascasarjana, Univesitas Negeri Yogyakarta, Yogyakarta, Indonesia, 12920

Dyah Kumalasari, Fakultas Ilmu Sosial, Univesitas Negeri Yogyakarta, Yogyakarta, Indonesia, 12920

Joniel Hendrik Salouw, Pendidikan Pancasila dan Kewarganegaraan, Program Pascasarjana, Univesitas Negeri Yogyakarta, Yogyakarta, Indonesia, 12920

E-mail: laaru1892@gmail.com

UDC 37:061.2(477.85)"186/193"

DOI: $10.15587 / 2519-4984.2020 .220482$

\section{CONTENT OF CARE OF STUDENT YOUTH AND CHILDREN IN ACTIVITY OF UKRAINIAN COMMUNITIES AT BUKOVINA (end of XIX - 1914)}

\section{Zvozdetska}

The article elucidates the activity of Ukrainian communities at Bukovina of the second half of XIX to the end of the Austrian-Hungarian period ("Rusin Talk", "Rusin Rada", "Folk house”, "Rusin school”, "Sych", "Myronosistsy", "Women association" and others) in the sphere of social care over children and youth. The special attention is paid to one of great and long-term project - opening and keeping of bursas (dormitories for poor students and natives of rural territories). Causes of the necessity of such institutions are elucidated, the contingent of students, lived in bursas, financing sources, forms of costs involvement for provision and keeping of the institutions, content, forms and directions of learning-upbringing work, realized in bursas, also content of work and a circle of duties of workers of such institutions are described. The article substantiates the importance of bursas functioning for forming national consciousness by involving students in different types of educative work. Form and types of social support and help, such as: cloth and accommodation supply for poor students, opening and keeping of bursas (dormitories); textbook and school accessories supply; monetary "address" payments for poor students, organization of free food for them; help for sick persons; orphan house support are concretized. The activity of communities and separate famous persons in Bukovina in organization of the system of payments for charity projects and creation of special funds is noted. Based on studying archive documents, materials of periodicals, special literature, the review of concrete cases of the charity direction, realized by Ukrainian communities at Bukovina in the studied period, is presented

Keywords: public welfare, public organizations, schools, history of public welfare in Bukovina

Copyright (C) 2020, V. Zvozdetska. This is an open access article under the CC BY license (http://creativecommons.org/licenses/by/4.0).

\section{Introduction}

Changes of main directions and priorities of socio-economic development of modern Ukraine concern functioning of all social institutions.

Economic stratification of the society, appearance of social groups, different by material status, poor financing of social programs in first turn touches children and youth - the weakest and most vulnerable population category.

Social adaptation of children and youth to new economic, political and cultural conditions, formation of life experience that would be a barrier for deviant behavior forms in the growing generation, protection of children's rights and realization of their interests, prevention of abusive treatment of children and their rehabilitation - it is only a small list of questions, adjacent to the problem of childhood and its social protection. It is obvious, that these problems must be solved through the activity of state, pubic organizations, education system at all its levels.

\section{Literary review}

It is important for organizing social protection of children and youth to study the historical experience of this phenomenon, critical understanding of which allows to use best achievements maximally and to integrate 